\title{
Maya mortuary landscapes, Central Belize
}

\author{
Gabriel Wrobel ${ }^{1, *}$, Amy Michael ${ }^{2}$, Jack Biggs ${ }^{1}$, Christophe Helmke ${ }^{3}$, \\ Shawn Morton ${ }^{4} \&$ Christopher Andres ${ }^{1}$
}

\section{Central Belize}

The Central Belize Archaeological Survey (CBAS) was initiated in 2005 as a sub-project of the Belize Valley Archaeological Reconnaissance project (BVAR; directed by Jaime Awe) to investigate the prehistoric Maya cemetery site of Caves Branch Rockshelter. Subsequently, we began to survey other nearby cave and rockshelter sites (Hardy 2009) and to excavate the monumental civic-ceremonial centre of Deep Valley (Jordan 2008). CBAS became an independent project in 2009, with an increasing focus on sites in the neighbouring Roaring Creek Valley (Figure 1). This slight geographic shift was in part intended to expand bioarchaeological investigations to include dark zone cave contexts identified during the late 1990s by BVAR's Western Belize Regional Cave Project. In the area around these caves, we identified two large, previously unreported civic-ceremonial centres and a network of raised roads (sacbeob) connecting them and other sites. Our survey and excavations at Tipan Chen Uitz (Figure 2) have yielded evidence that it was a regional capital with ties to powerful foreign polities, as attested by the discovery of multiple carved stone monuments (Figure 3; see Andres et al. 2014; Helmke \& Andres 2015; Andres et al. in press in Antiquity). We have also continued our investigations of mortuary rockshelters, including Sapodilla Rockshelter in the Caves Branch Valley.

Our work has demonstrated the importance of including archaeological data from caves and rockshelters in regional historical reconstructions. Specifically, excavations of monumental architecture by CBAS and others at the centres of surface sites and surrounding settlements have identified very few ceramics dating to before the Middle Classic period (c. AD 550). Late Preclassic and Early Classic sherds, however, are ubiquitous in rockshelters and in many caves, especially around their entrances. These provide evidence of a sizeable early rural population who, thus far, have remained otherwise archaeologically invisible. While the use of these sites is thought to be largely ritualistic in nature, artefacts

1 Department of Anthropology, Michigan State University, 655 Auditorium Drive, East Lansing, MI 48824, USA (Email:wrobelg@msu.edu; biggsjac@msu.edu; kipandres@hotmail.com)

2 Department of Anthropology, Idaho State University, 921 S. $8^{\text {th }}$ Avenue, Pocatello, ID 83209, USA (Email: michae76@msu.edu)

3 Institute for Cross-cultural and Regional Studies, University of Copenhagen, Karen Blixens Plads 8, DK-2300 Copenhagen S, Denmark (Email: cgbh@hum.ku.dk)

4 Department of Anthropology, Northern Arizona University, 5 E. McConnell Drive, Flagstaff, AZ 86011, USA (Email:shawn.morton@nau.edu)

* Author for correspondence (Email: wrobelg@msu.edu)

(C) Antiquity Publications Ltd, 2017 ANTIQUITY 91 358, e5 (2017): 1-7 


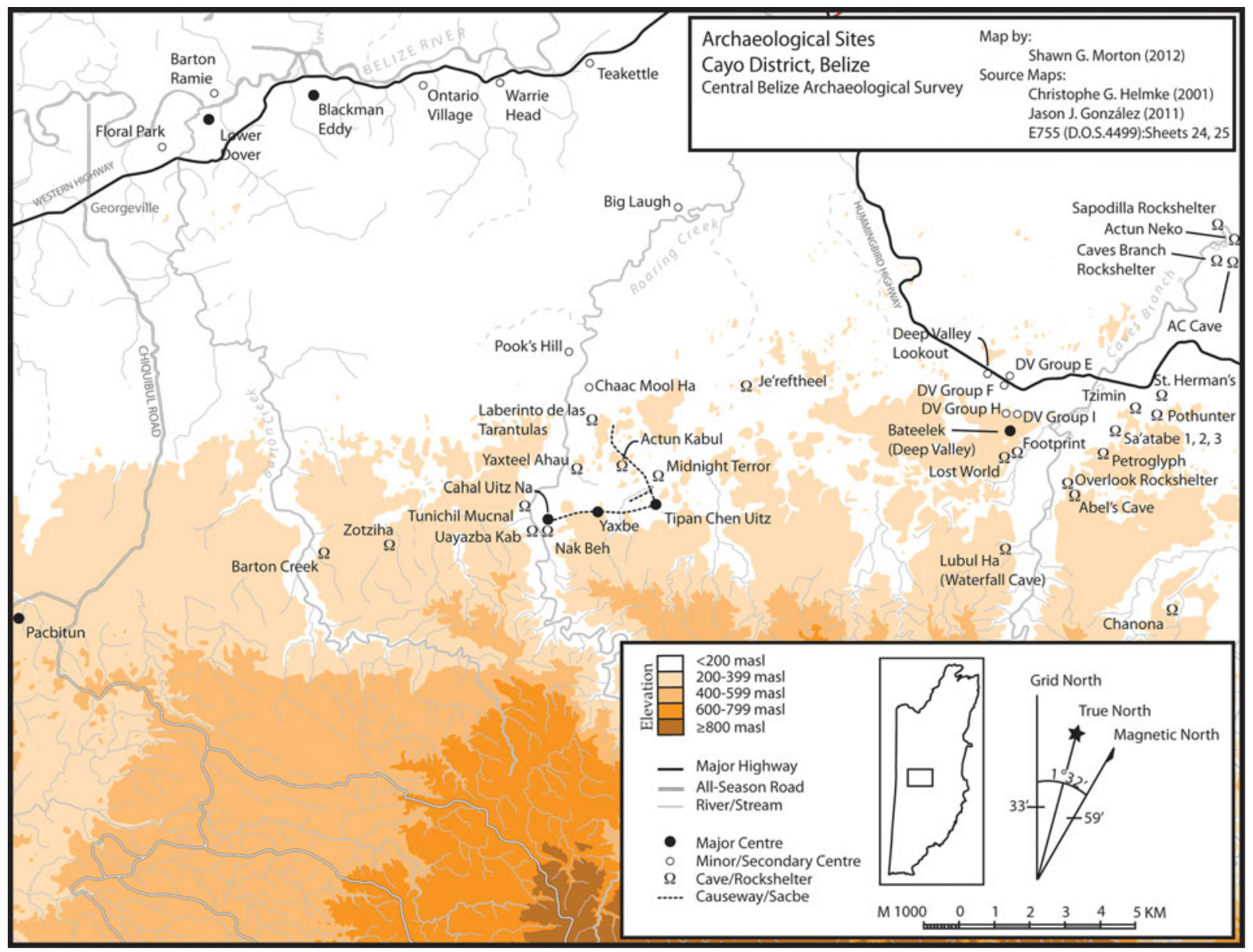

Figure 1. Map of Central Belize. The Central Belize Archaeological Survey research area includes sites located around the Roaring Creek and Caves Branch Rivers, but not those in the northern and western areas of the map. 


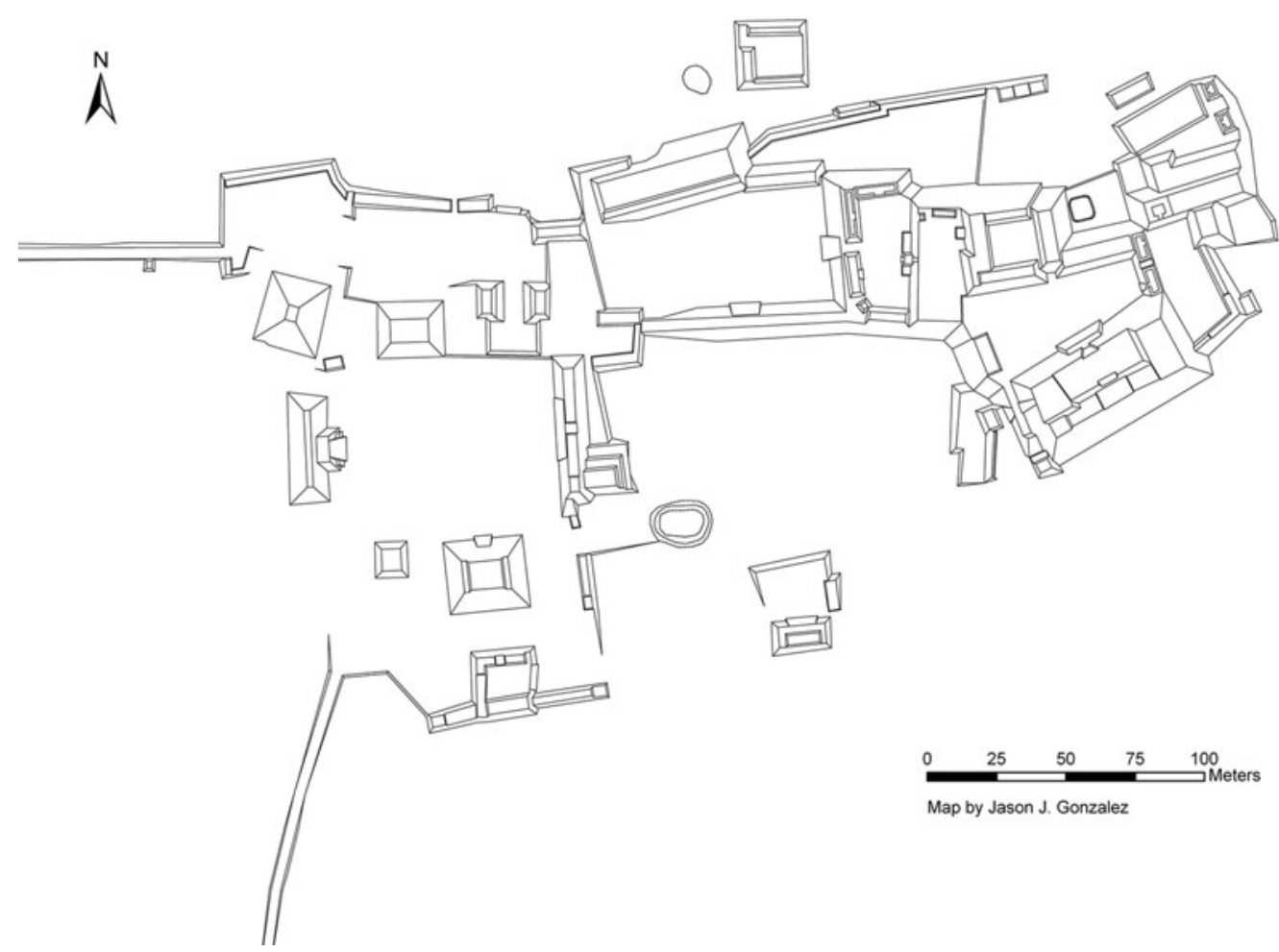

Figure 2. Plan of Tipan Chen Uitz.

deposited in caves and rockshelters by members of local communities also provide data that are useful in studying aspects of social, economic and political organisation (Morton et al. 2015).

\section{Mortuary deposits}

Mortuary deposits have provided some of the most interesting insights into the nature of social organisation in the region. While individual sites all have unique use-histories, varying widely in the number of individuals (from just a few to well over 100), in patterns of intentional and unintentional secondary movement of bones, and in the timing and intensity of use, caves and rockshelters demonstrate several important and broadly consistent differences. Rockshelters, located beneath natural overhangs along rock faces, are easily accessible and visible with natural light. Accordingly, their usage appears rather unrestricted. Our two largest rockshelters, both in the more rural Caves Branch River Valley, show age and sex distributions that appear to conform to expected mortality profiles, and individuals were treated simply—placed in small pits with few or no grave goods (Figure 4). For the most part, secondary movement of bones appears unintentional, resulting from disturbance while digging newer graves. This general pattern of burial in rockshelters began 


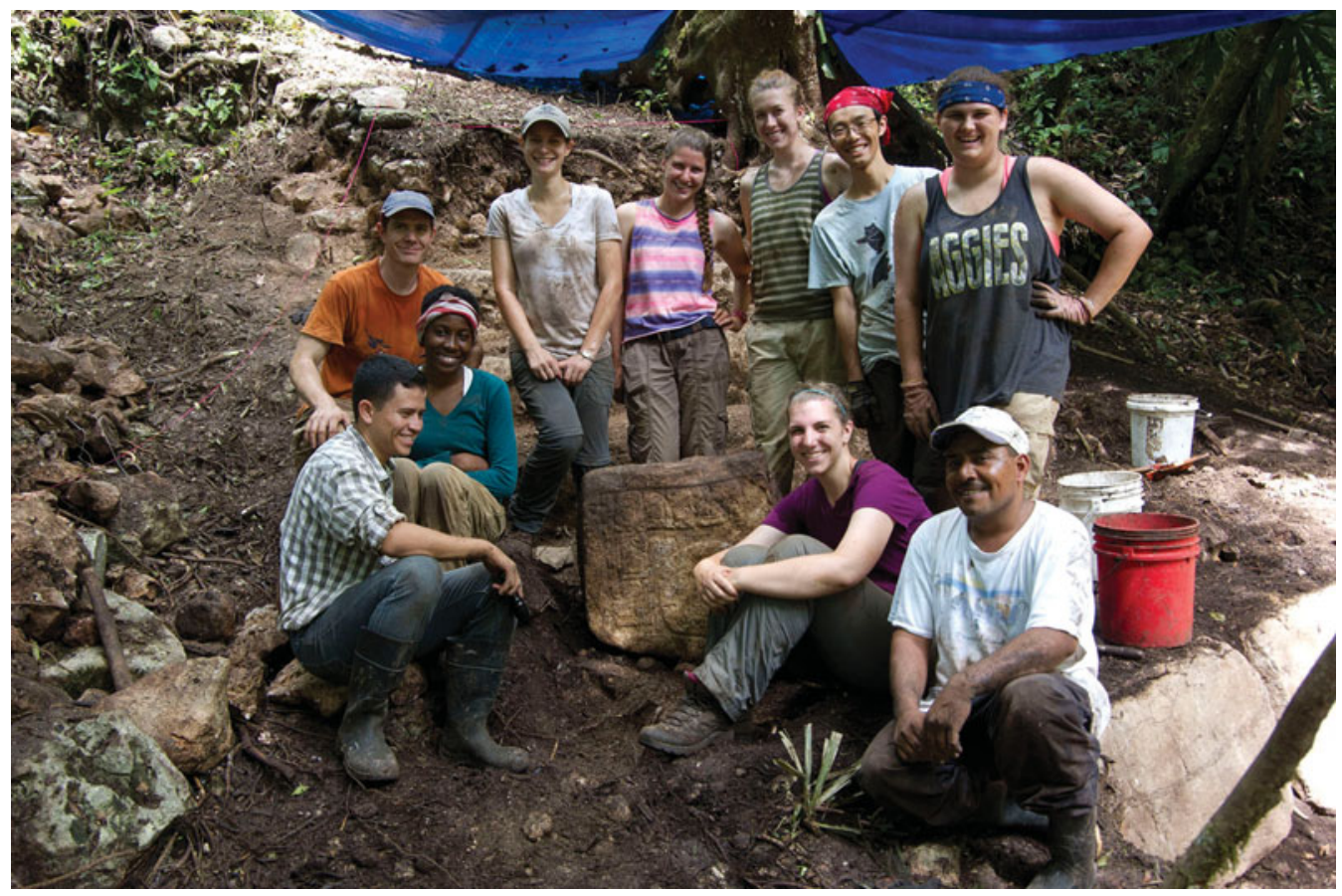

Figure 3. Tipan Chen Uitz monument 3 (photograph by S. Morton).

in Central Belize by the Late Preclassic period (300 BC-AD 300), presumably coinciding with the local establishment of small agricultural communities, and continued until the area's depopulation, probably during the eighth or ninth centuries AD. Within the Roaring Creek Valley, however, mortuary use of the cave site at Actun Uayazba Kab ceases around the time that the surrounding area was being urbanised, after which the site was probably used for rain-related rituals (Wrobel et al. 2017).

Thus far, associated ceramics and direct AMS dates indicate that the mortuary use of dark-zone caves was later, coinciding with the period of local urbanisation, or, perhaps, with Late Classic period droughts thought to have, in part, led to the collapse of citystates in the Central Lowlands. Mortuary contexts in caves are more restrictive-they are typically located within the deepest chambers, and are thus often difficult to reach and required artificial light from pine torches. While cave burials seem to demonstrate equal numbers of males and females, it is clear that age guided inclusion. Specifically, it is rare to find infants under the age of three, or middle-aged and older adults. The meaning of this restriction is debated. Some have pointed to parallels with ethnohistoric accounts from the colonial Yucatan of sacrificial rituals associated with rain ceremonies, in which young individuals - usually children around the age of five to seven years-were killed and deposited in cenotes. Our analyses of age distributions in the caves, however, do not show obvious over-representation of that specific age range relative to adolescents and young adults. We also find evidence that individuals in caves often underwent (C) Antiquity Publications Ltd, 2017 


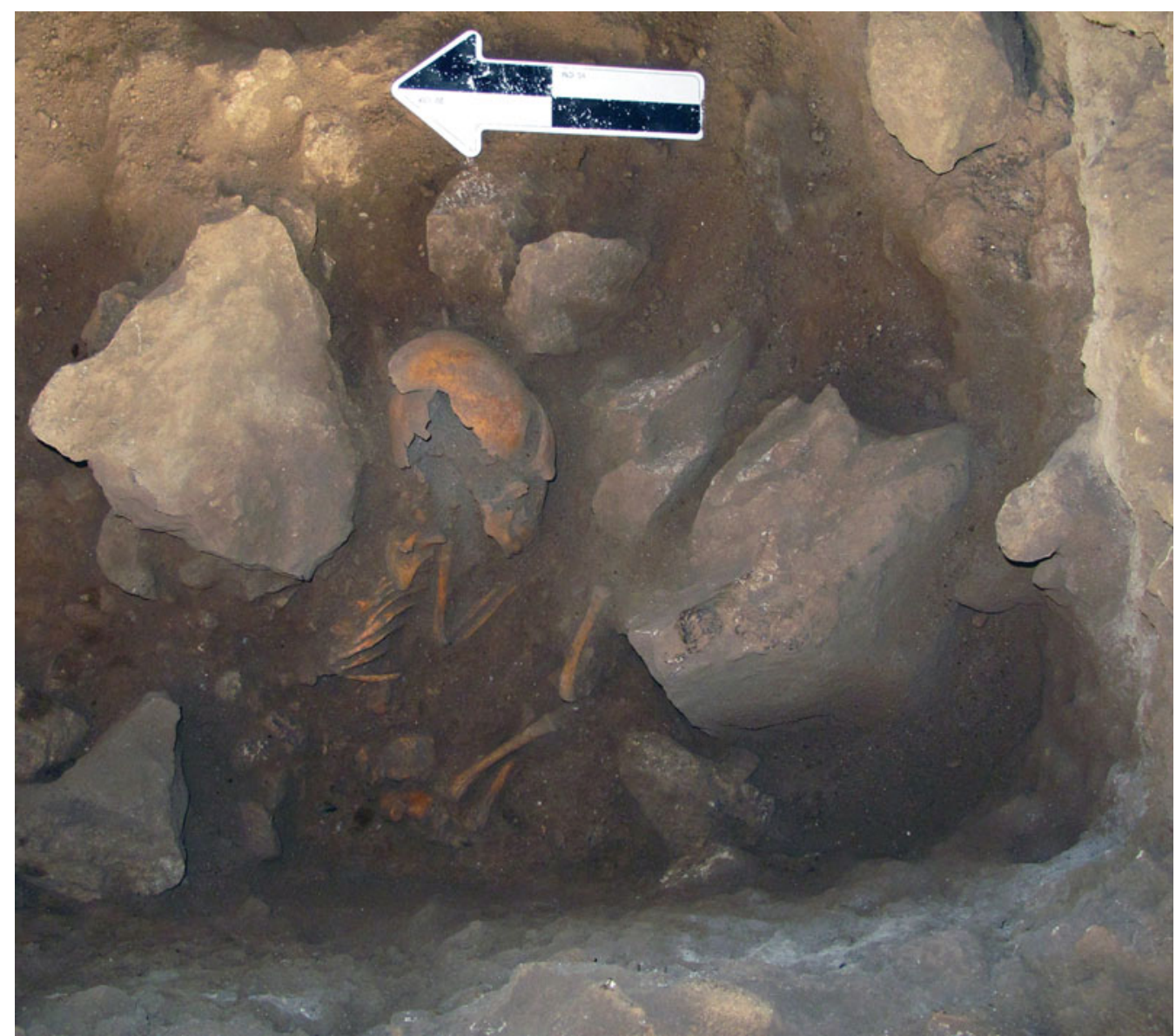

Figure 4. Simple pit burial of an infant from Sapodilla Rockshelter (photograph by G. Wrobel).

complex and prolonged mortuary treatments that are consistent with documented elite funerary programmes (Wrobel et al. 2014). Thus, we believe that the use of cave chambers was, at least in some cases, analogous to that of tombs (Figure 5), and therefore served to house a sub-group that was socially distinct from the rural farmers placed in rockshelters.

Although comparisons of dental micro- and macroscopic indicators (Wilson bands, linear enamel hypoplasia, caries) demonstrate relatively good health among all burial groups (Michael 2016), comparisons of cranial and dental modification prevalence have found that individuals from caves had relatively high frequencies of both modifications, while modifications were almost completely absent within rockshelters (Figure 6). In this way, individuals distinguished in death by their placement in caves were also marked as distinct in life from those who would be buried in rockshelters. Future investigations of these contexts will continue to document indicators of social identity, with the goal of linking mortuary ritual to broader social and political developments in Central Belize. 


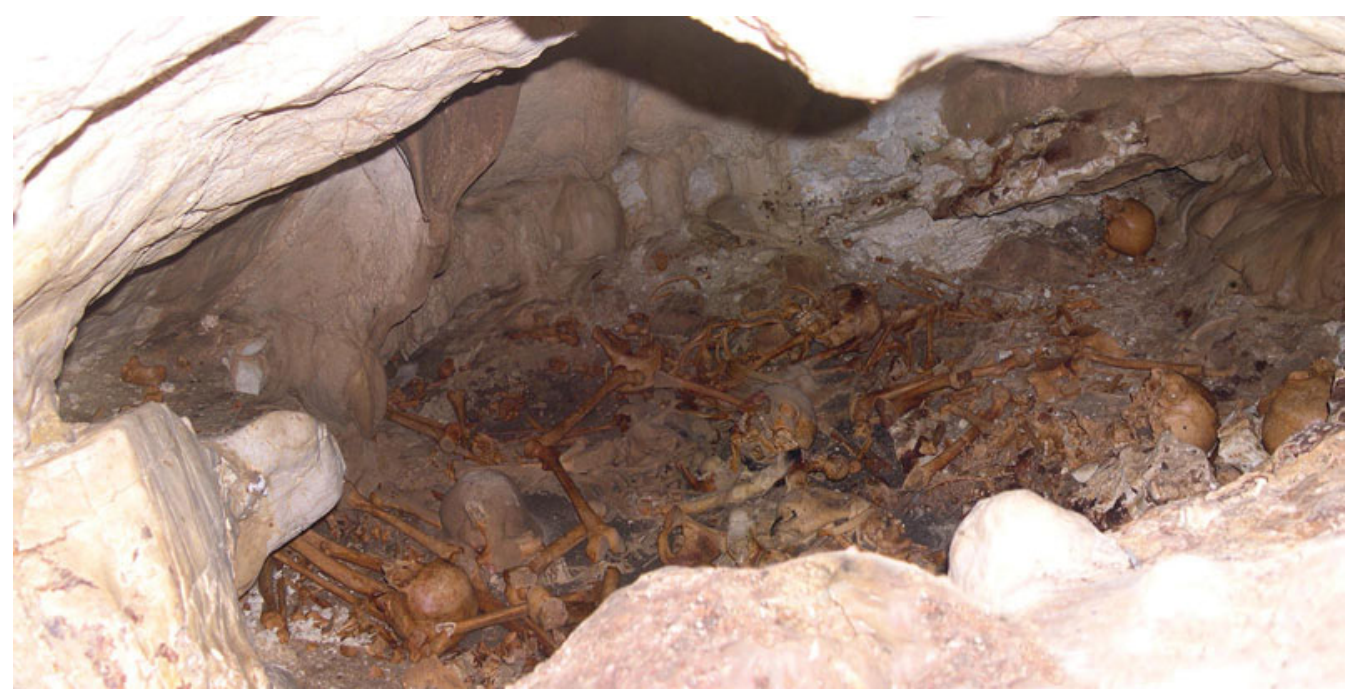

Figure 5. The ossuary from chamber 3 within the cave site of Je'reftheel (photograph by C. Helmke).

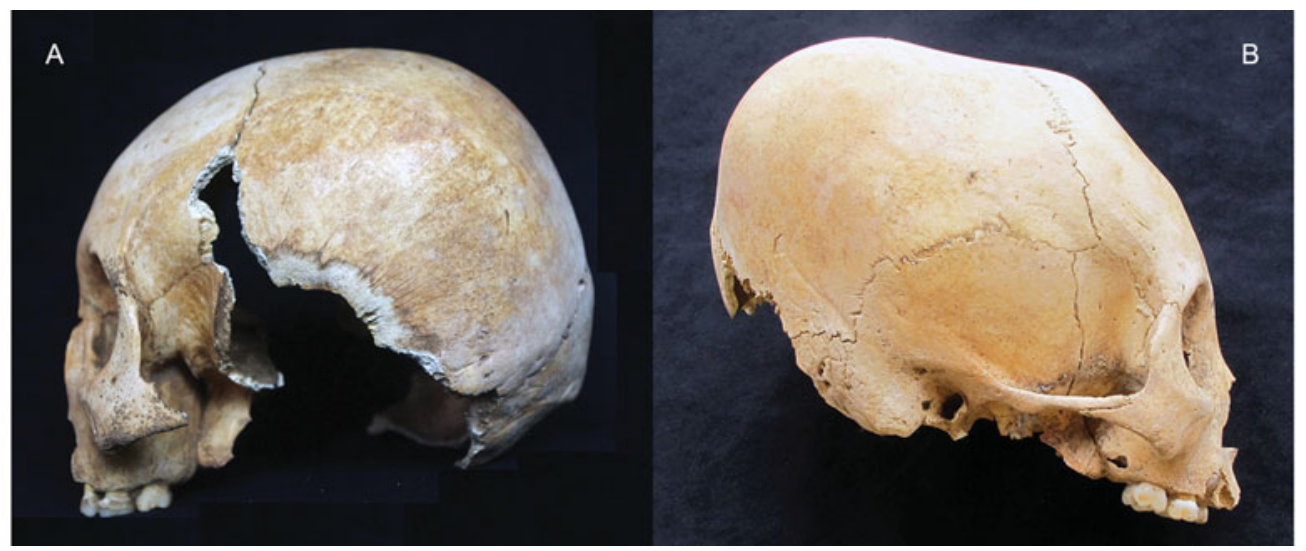

Figure 6. a) An unmodified cranium from Sapodilla Rockshelter; b) a cranium with tabular erect modification and a post-coronal sulcus from Actun Kabul, a dark-zone cave (photographs by G. Wrobel).

\section{Acknowledgements}

Thanks go to all of the researchers in the region upon whose work we have relied to inform our own, in particular to Jaime Awe, Cameron Griffith, Rafael Guerra and the staff of the Western Belize Regional Cave Project; Elizabeth Graham; and Juan Luis Bonor. We also send special thanks to John Morris and the staff of the Belize Institute of Archaeology, and to the people and communities in Central Belize, who have supported us and helped us conduct this research, including Dave and Patti Hayles, Ian and Ella Anderson, and members of Armenia and Springfield villages_-in particular our local collaborators: Hugo Claro, Neko Medrano, Abel Garcia and Gonzo Pleitez. Research support for this project has come from the University of Mississippi, Michigan State University, the University of Copenhagen, the University of Calgary and Indiana University

(C) Antiquity Publications Ltd, 2017 


\section{Maya mortuary landscapes, Central Belize}

(Bloomington and Fort Wayne). Finally, thanks go to all of the former staff and students of the CBAS and BVAR projects.

\section{References}

Andres, C., C.G.B. Helmke, S.G. Morton, G.D. Wrobel \& J.J. GonZÁlez. 2014. Contextualizing the glyphic texts of Tipan Chen Uitz, Cayo District, Belize. Latin American Antiquity 25: 46-64. https://doi.org/10.7183/1045-6635.25.1.46

Andres, C., C. Helmke, S. Morton \& G.D. Wrobel. In press. Two ballplayer panels from Tipan Chen Uitz, Belize. Antiquity 91.

Hardy, J. 2009. Understanding functional and symbolic variation in rockshelters of the Caves Branch River Valley of western Belize, Central America. Unpublished MA dissertation, University of Mississippi.

Helmke, C. \& C.R. Andres. 2015. Discovery and description of monument 2 at Tipan Chen Uitz, Belize. Mexicon 37(5): 112-17.

Jordan, J. 2008. Persistence in the periphery: archaeological investigations at Baateelek, Caves Branch River Valley, Belize. Unpublished MA dissertation, University of Mississippi.
Michael, A.R. 2016. Investigations of micro- and macroscopic dental defects in Pre-Hispanic Maya Cave and rockshelter burials in Central Belize. Unpublished PhD dissertation, Michigan State University, East Lansing.

Morton, S.G., M. Isa \& G. Wrobel. 2015. Caves were the houses of the Earth Lord, right?: insight into the domestic economy of Central Belize from the cave context. Research Reports in Belizean Archaeology 12: 107-14.

Wrobel, G.D., C.G.B. Helmke \& C. Freiwald. 2014. A case study of funerary cave use from Je'reftheel, Central Belize, in G.D. Wrobel (ed.) The bioarchaeology of space and place: ideology, power and meaning in Maya mortuary contexts: 77-106. New York: Springer. https://doi.org/10.1007/978-1-4939-0479-2_4

Wrobel, G.D., C. Freiwald, A.R. Michael, C.G.B. Helmke, J.J. Awe, D.J. Kennett, S. GibBs, J.M. Ferguson \& C. Griffth. 2017. Social identity and geographic origin of Maya burials at Actun Uayazba Kab, Roaring Creek Valley, Belize. Journal of Anthropological Archaeology 45: 98-114.

https://doi.org/10.1016/j.bbr.2011.03.031 